\title{
PERSEPSI MASYARAKAT MENGENAI KEMITRAAN BANK SYARIAH TERHADAP REPUTASI BANK SYARIAH
}

\section{THE PUBLIC PERCEPTION OF THE PARTNERSHIPS TO THE REPUTATION OF ISLAMIC BANKS ISLAMIC BANKS}

\author{
Dewi Sufi Alawiyah'1a; Andri Brawijaya ${ }^{2 b}$ \\ 1aJurusan Ekonomi Islam Fakultas Perbankan Syariah Universitas Djuanda, Jl. Tol Ciawi \\ No. 1, Kotak Pos 35 Bogor 16720 \\ 2bJurusan Perbankan Syariah Fakultas Ekonomi Islam Universitas Djuanda, Jl. Tol Ciawi \\ No. 1, Kotak Pos 35 Bogor 16720
}

(Diterima oleh Dewan Redaksi 10-06-2016)

(Dipublikasikan oleh Dewan Redaksi 01-12-2016)

\begin{abstract}
This study aims to determine how the public perception about the partnership of Islamic banks and Islamic banks reputation. Using descriptive method and quantitative analysis method using Likert scale and Chi Square. The primary data obtained by questionnaire and sampling methods Slovin of 100 samples of the population of the city of Bogor. The calculation results show that the public Likert Scale Bogor have varying perceptions about the partnership of Islamic banks and Islamic banks reputation, it is influenced by several factors,such as level of education and information obtained by each individual. Calculations using Chi Square value of 84,100. Chi Square test result greater than the Chi Square table that is $84,100>13,277$ so that Ho was rejected and Ha received or may be concluded that the public knows partnerships Islamic banks and Islamic banks reputation.
\end{abstract}

Keywords: Perception, Society, Partnership, Reputation

\begin{abstract}
ABSTRAK
Penelitian ini bertujuan untuk mengetahui bagaimana persepsi masyarakat mengenai kemitraan bank syariah dan reputasi bank syariah. Menggunakan metode deskriptif kuantitatif dan menggunakan analisis metode Skala Likert dan Chi Kuadrat. Data primer yang diambil dengan metode kuesioner dengan pengambilan sampel menggunakan metode Slovin sebanyak 100 sampel dari populasi masyarakat kota Bogor. Hasil perhitungan Skala Likert menunjukan bahwa masyarakat Kota Bogor mempunyai persepsi yang bervariasi mengenai kemitraan bank syariah dan reputasi bank syariah, hal ini dipengaruhi oleh beberapa faktor, seperti tingkat pendidikan dan informasi yang diperoleh oleh setiap individu. Perhitungan dengan metode Chi Kuadrat diperoleh nilai sebesar 84.100. Maka hasil Chi Kuadrat hitung lebih besar daripada Chi Kuadrat tabel yaitu $84.100>13.277$ sehingga Ho dalam penelitian ini ditolak dan Ha diterima atau dapat disimpulkan bahwa masyarakat mengetahui kemitraan bank syariah dan reputasi bank syariah.
\end{abstract}

Kata kunci : Persepsi, Masyarakat, Kemitraan, Reputasi 
Sufi Alawiyah, D. 2016. Persepsi Masyarakat mengenai kemitraan Bank Syariah Trhadap Reputasi Bank Syariah. Jurnal Nisbah. (4): 265 - 282

\section{PENDAHULUAN}

Sistem perbankan di Indonesia memiliki dual system, yaitu bank konvensional dan bank syariah. Dalam hal ini untuk memperluas perkembangan bank syariah, maka bank konvensional membuka kebijakan yang diterbitkan oleh Bank Indonesia (BI). Kebijakan tersebut dituangkan dalam Peraturan Bank Indonesia (PBI) Nomor 9 Tahun 2007 tentang penilaian kualitas aktiva bank umum yang melaksanakan kegiatan usaha berdasarkan prinsip syariah. Kebijakan tersebut mengizinkan UUS untuk menyalurkan pembiayaan melalui kantor cabang office channelling konvensional. Tujuannya agar dapat mempercepat pertumbuhan perbankan syariah. Menurut Undang-Undang Nomor 21 Tahun 2008 Bab 1 Pasal 1 ayat 10, Unit Usaha Syariah adalah unit kerja dari kantor pusat Bank Umum Konvensional yang berfungsi sebagai kantor induk dari kantor atau unit yang melaksanakan kegiatan usaha berdasarkan prinsip syariah, atau unit kerja di kantor cabang dari suatu Bank yang berkedudukan di luar negeri yang melaksanakan kegiatan usaha secara konvensional yang berfungsi sebagai kantor induk dari kantor cabang pembantu syariah dan/atau unit syariah (Remy Sjahdeini, 2014:102-103).

Bank berdasarkan syariat Islam adalah lembaga perbankan yang menggunakan sistem dan operasinya berdasarkan syariat Islam. Ini berarti operasi perbankannya mengikuti tata cara berusaha maupun perjanjian berusaha yang berdasarkan Al-Qur'an dan Al-hadits. Bank syariah menggunakan ide tentang sistem bagi hasil dan tidak menggunakan bunga sebagaimana dipraktikkan oleh bank konvensional. Adapun tujuan didirikannya bank Islam adalah untuk menerapkan ajaran Allah SWT secara konsekuen dalam larangan perekonomian dan bisnis dan menghindarkan masyarakat Islam dari larangan-larangan agama (Aziz, 1993:31).

Dalam hal pengetahuan masyarakat tentang bank syariah akan mempengaruhi pandangan masyarakat terhadap bank syariah itu sendiri. Sebagian masyarakat menilai, bahwa bank syariah memberikan pelayanan transaksi yang halal, adanya hubungan tolong menolong antar sesama, dan memiliki keselamatan akhirat karena terhindar dari riba. Dengan masih kurangnya pemahaman masyarakat akan pemahaman Islam, maka masalah perbankan bahkan perekonomian secara lebih luas maka perbankan syariah harus terus berkembang dan memperbaiki kinerjanya. Dalam hal ini bank syariah penting memperkenalkan kepada kalangan masyarakat, dengan cara membangun jaringan-jaringan luas dengan lembaga lain, agar bank syariah dapat dikenal oleh kalangan masyarakat. Perbankan syariah akan semakin terus meningkat tinggi pertumbuhannya apabila masyarakat memiliki permintaan yang tinggi dikarenakan faktor peningkatan pengetahuan tentang bank syariah.

Dalam perkembangan di antara bank-bank syariah pada saat ini, dibutuhkan strategi kemitraan untuk tercapainya kesejahteraan individu maupun masyarakat. Untuk meningkatkan pertumbuhan ekonomi mempermudah masyarakat dalam mengetahui tentang informasi, transaksi, dan bisnis lainnya. Kemitraan dapat membuat bank syariah memahami atas adanya harapan serta 
kebutuhan masyarakat. Suatu pengalaman yang menyenangkan dari hubungan kemitraan yang dijalin oleh bank syariah dengan perusahaan/lembaga lain akan menciptakan kesan yang sangat baik yang dapat diingat oleh masyarakat, hal ini dapat memelihara reputasi bank syariah. Dalam jangka panjang kemitraan bank syariah dapat menciptakan sebuah reputasi yang baik, serta meningkatkan kepercayaan masyarakat.

Berdasarkan uraian diatas, penulis ingin mengetahui tentang ada atau tidaknya pengaruh kemitran bank syariah. Atas dasar tersebut penulis mencoba untuk membahas masalah "Persepsi Masyarakat Mengenai Pengaruh Kemitraan Bank Syariah Terhadap Reputasi Bank Syariah".

\section{MATERI DAN METODE}

\section{Jenis dan Objek penelitian}

Jenis penelitian ini merupakan jenis penelitian deskriptif kuantitatif, dimana penelitian ini bermaksud untuk memberikan gambaran mengenai pengaruh kemitraan bank syariah terhadap reputasi bank dalam persepsi masyarakat.

Objek penelitian pada penelitian ini adalah masyarakat yang berada di kota Bogor dengan fokus penelitian adalah persepsi masyarakat mengenai kemitraan bank syariah terhadap reputasi bank syariah.

\section{Jenis dan Sumber Data}

Jenis dan sumber data yang digunakan dalam penelitian ini adalah :

a. Data primer adalah data yang dikumpulkan sendiri oleh peneliti langsung dari sumber pertama atau tempat obyek penelitian dilakukan. Dalam penelitian ini data primer yang didapatkan melalui kuesioner yang disebarkan pada masyarakat kota Bogor dan wawancara.

b. Data sekunder adalah data yang digunakan oleh organisasi yang bukan pengolahanya. Data tersebut terdiri daridokumen-dokumen, buku, jurnal, internet dan beberapa literatur lainnya yang ada hubugannya dengan penelitian yang dilakukan.

\section{Teknik Pengumpulan Data}

Pengumpulan data adalah suatu proses pengumpulan data primer dan sekunder dalam suatu penelitian. Pengumpulan data merupakan langkah yang amat penting, karena data yang dikumpulkan akan digunakan untuk pemecahan masalah yang sedang diteliti atau menguji hipotesis yang telah dirumuskan. Teknik pengumpulan data yang dilakukan dalam penelitian ini adalah melalui kuesioner, yaitu suatu teknik pengumpulan informasi yang memungkinkan analis mempelajari sikap-sikap, keyakinan, perilaku, dan karakteristik beberapa orang. Teknik penyebaran kuesioner dilakukan secara langsung diberikan kepada responden yang menjadi sampel.

\section{Teknik Analisis Data}

Teknik analisis data yang digunakan dalam penelitian ini adalah skala likert dan chi-square dengan beberapa tahap sebagai berikut:

a. Statistik Deskriptif adalah statistik yang digunakan untuk menganalisis data dengan cara mendeskripsikan atau menggambarkan data yang telah terkumpul sebagaimana adanya tanpa bermaksud membuat kesimpulan yang berlaku untuk umum atau generalisasi (Sugiyono, 2012).

b. Uji Validitas Item adalah uji statistik yang digunakan guna menentukan seberapa valid suatu item pertanyaan mengukur variabel yang 
diteliti. Uji Validitas Item atau butir dapat dilakukan dengan menggunakan software SPSS. Untuk proses ini, akan digunakan Uji Korelasi Pearson Product Moment. Dalam uji ini, setiap item akan diuji relasinya dengan skor total variabel yang dimaksud. Dalam hal ini masing-masing item yang ada di dalam variabel $\mathrm{X}$ dan $\mathrm{Y}$ akan diuji relasinya dengan skor total variabel tersebut.

c. Uji Reliabilitas item adalah uji statistik yang digunakan guna menentukan reliabilitas serangkaian item pertanyaan dalam kehandalannya mengukur suatu variabel.

d. Skala likert digunakan untuk mengukur sikap, pendapat dan persepsi seseorang atau sekelompok orang tentang fenomena sosial (Sugiyono, 2015:136). Dengan skala likert, maka variabel yang akan diukur dijabarkan menjadi indikator variabel. Kemudian indikator tersebut dijadikan sebagai titik tolak untuk menyusun item-item instrumen yang dapat berupa pernyataan atau pertanyaan.

e. Test Chi-Kuadrat (Chi-Square) adalah salah satu penggunaan statistik adalah untuk memutuskan apakah sebuah hipotesis di tolak atau tidak, teknik ini dilakukan apabila jumlah pupulasi lebih dari 30. Teknik ini cocok digunakan pada penelitian ini untuk mengetahui keadaan hipotesisnya.

\section{Perkembangan Industri Bank Umum Syariah}

Persaingan industri jasa keuangan akan berpengaruh negatif terhadap kinerja perbankan syariah, hal ini dikarenakan terdapat beberapa permasalahan seperti jumlah modal yang terbatas, Sumber Daya Manusia
(SDM) yang belum mumpuni, fasilitas teknologi informasi dan masih banyak lagi keterbatasan lainnya yang belum dapat menunjang kegiatan/operasional bank syariah secara maksimal.

Perkembangan bank umum syariah (BUS) relatif stagnan/tetap dengan arti tidak mengalami pertumbuhan, bahkan jika dilihat lebih lanjut jumlah kantor pada bank tersebut malah mengalami penurunan dari bulan ke bulannya. Hal ini sangat bertentangan dengan harapan yang seharusnya dipikul oleh bank syariah dalam hal memberikan dampak perbaikan kepada masyarakat dan mendukung pertumbuhan perekonomian di Indonesia. Bank syariah mengalami pelambatan pertumbuhan bahkan penurunan market share dibandingkan bank konvensional. Bank syariah harus memiliki produk yang inovatif yang semakin berkembang.

\section{Gambaran Umum Kota Bogor}

Kota Bogor adalah salah satu kota di Provinsi Jawa Barat, yang terletak di sebelah selatan Ibukota Jakarta. Kota berlambangkan kujang ini terkenal akan julukan kota hujan dan merupakan suatu wilayah yang secara fisik berbentuk "Kota dalam Taman". Kebun Raya Bogor (Botanical garden) adalah salah satu ikon kota yang terkenal dalam dunia pariwisata maupun ilmiah.

Kedudukan topografis kota seluas $11.850 \mathrm{Ha}$ ini yang berada di tengah wilayah Kabupaten Bogor, serta lokasinya yang dekat dengan ibukota negara serta didukung dengan kedudukan Kota Bogor diantara jalur tujuan Puncak/Cianjur, merupakan potensi yang strategis untuk perkembangan dan pertumbuhan kegiatan ekonomi. Menurut Badan Pusat Statistik, Kota Bogor memiliki tingkat pertumbuhan penduduk hingga 1.89\%, dengan jumlah peduduk pada tahun 2014 sebanyak 1.030 .720 .00 jiwa. 
Dengan jumlah penduduk cukup besar serta tingginya kegiatan di sektor ekonomi dan jasa, berdampak pada meningkatnya mobilitas penduduk Kota Bogor, baik secara internal maupun eksternal. (BPS Kota Bogor).

\section{Analisis Data}

1. Perhitungan Statistik Deskriptif (Frequency)

Jumlah responden yang diteliti adalah sebanyak 100 orang. Penelitian ini dilihat dari karakteristik masyarakat yang terdiri dari jenis kelamin, usia, tempat tinggal, pendidikan akhir, agama, lokasi kerja, pekerjaan, dan pendapatan pendapatan tiap bulan.

a. Jenis kelamin responden

Jenis kelamin responden yang dominan adalah perempuan 60 orang (60\%), dan jenis kelamin laki-laki 40 orang (40\%). Dari data tersebut diketahui bahwa selisih responden lakilaki dan perempuan hanya 10 orang. Dalam data ini menyatakan bahwa responden dominan perempuan karena jumlah perempuan di kota bogor lebih banyak dibandingkan dengan jumlah responden laki-laki.

b. Tingkat usia responden

Tingkat usia responden yang dominan adalah 20-29 tahun 39 orang (39\%), 41-50 tahun 25 orang (25\%), $>50$ tahun (50\%), $16-19$ tahun 6 orang $(6 \%)$, dan $<15$ tahun 0 orang $(0 \%)$. Dari data tersebut dapat diketahui bahwa umur responden yang berusia 20-29 tahun lebih besar, karena masyarakat kota bogor masih dominan dengan usia produktif.

c. Tingkat pendidikan akhir
responden
Tingkat pendidikan responden yang dominan adalah Sarjana 52 orang (52\%), SMU 34 orang (34\%), Diploma 11 orang $(11 \%)$, dan SMP 1 orang (1\%). Dari data diatas dapat diketahui bahwa tingkat pendidikan yang dominan adalah sarjana, karena masyarakat kota
Bogor lebih mengutamakan tingkat pendidikannya.

d. Jenis Agama Responden

Jenis agama dari responden yang dominan adalah agama Islam dengan persentase 100\%. Dengan demikian diketahui bahwa semua responden memeluk agama Islam. Dari data diatas dapat disimpulkan bahwa mayoritas masyarakat kota Bogor memeluk agama Islam.

e. Lokasi Kerja responden

Lokasi kerja responden yang dominan adalah di Bogor 61 orang (61\%), di Jakarta 30 orang (30\%), di Depok 4 orang (4\%), Pegawai Negri Sipil 8 orang $(8 \%)$, Wiraswasta 6 orang (6\%), dan lokasi kerja lainnya 5 orang (5\%). Dari data diatas dapat diketahui bahwa lokasi kerja yang paling dominan adalah Bogor, hal ini dikarenakan jangkauan lokasi tempat tinggal lebih dekat dengan lokasi kerja responden.

f. Pekerjaan responden

Jenis pekerjaan responden yang dominan adalah pegawai swasta 49 orang (49\%), pelajar/mahasiswa 17 orang (17\%), Ibu Rumah Tangga 15 orang (15\%), Pegawai Negri Sipil 8 orang $(8 \%)$, Wiraswasta 6 orang $(6 \%)$, dan jenis pekerjaan lainnya 5 orang (5\%). Dari data di atas dapat diketahui bahwa jumlah pegawai swasta paling banyak dibandingkan dengan pegawai Negri Sipil, hal tersebut dikarenakan peluang untuk memperoleh posisi PNS, peminatnya lebih banyak dan mekanisme pendaftarannya lebih sulit.

g. Tingkat pendapatan tiap bulan responden

Tingkat pendapatan tiap bulan responden yang dominan adalah 2-3 juta sebanyak 40 orang (40\%), > 3 juta sebanyak 24 orang sementara $<1$ juta 29 orang (29\%), dan 1-2 Juta 7 orang (7\%). Dari data diatas tingkat pendapatan lebih dominan adalah 2-3 juta, karena hal tersebut sesuai dengan jenis pekerjaannya. 
2. Uji Reliabilitas

Reliabilitas adalah istilah yang dipakai untuk menunjukkan sejauhmana suatu hasil pengukuran relatif konsisten apabila alat ukur itu digunakan berulang kali, langkah lain jangan dijadikan alat untuk mengukur panjang karena tiap-tiap langkah tidak sama panjangnya (Abdullah, 2015:256).

Kuisioner dinyatakan jika mempunyai nilai koefisien alpha yang lebih besar daripada 0,6. Maka dari hasil tersebut pengujiannya dinyatakan reliable karena nilai koefisien croanbach's alpha diperoleh lebih besar dari nilai 0,6 yaitu $0,867(0,867>0,6)$. Sehingga hasil uji penelitian ini cukup handal dalam mengukur persepsi masyarakat terhadap variable yang akan diteliti dan dapat dilanjukten penelitian tersebut ke tahap selanjutnya.

3. Uji Validitas

Validitas adalah untuk meyatakan sejauhmana data yang didapatkan melalui instrumen penelitian (dalam hal ini kuesioner) akan mengukur apa yang ingin diukur (Abdullah, 2015:256). Uji validitas menunjukan sejauhmana suatu alat pengukur untuk mengukur apa yang akan diukur (Abdullah, 2015:258).

Dalam hasil pengolahan data tersebut, bahwa koefisien korelasi dari 25 pertanyaan yang ada, dapat disimpulkan 20 yang valid dengan skor $>0,361$ dan dapat diolah secara lanjut.

4. Perhitungan Skala Likert

a. Informasi Masyarakat Kota Bogor Mengenai Kemitraan Bank Syariah

1) Masyarakat Kota Bogor Mengetahui Mengenai Informasi Kemitraan Bank Syariah

Ternyatamasyarakat Kota Bogor yang "tahu" mengenai informasi tentang kemitraan bank syariah sebanyak 49 orang $(55,21 \%)$, sedangkan masyarakat Kota Bogor yang menjawab sangat tahu tentang kemitraan bank syariah sebanyak 11 orang $(15,50 \%)$. Dari perolehan angka penafsiran $\mathrm{M}=3,55$ menunjukkan bahwa pengetahuan masyarakat Kota Bogor tentang informasi bank syariah adalah " tahu".

2) Masyarakat mengetahui mengenai kemitraan bank syariah dari televisi

Dalam Penelitian ini, persepsi masyarakat Kota Bogor terhadap informasi tentang bank syariah ternyata masyarakat Kota Bogor yang "tahu" mengenai informasi tentang kemitraan bank syariah sebanyak 49 orang atau 55,21\%, sedangkan masyarakat Kota Bogor yang menjawab sangat tahu tentang bank syariah sebanyak 11 orang atau 15,50\%. Dari perolehan angka penafsiran $\mathrm{M}=3,47$ menunjukkan bahwa pengetahuan masyarakat Kota Bogor tentang informasi bank syariah adalah " tahu".

3) Masyarakat mengetahui tentang kemitraan bank syariah dari reklame/spanduk/leaflet

Dalam penelitian ini, masyarakat mengetahui tentang kemitraan bank syariah dari reklame/spanduk/leaflet adalah sebagai berikut: Dari tabel diatas ternyata masyarakat Kota Bogor yang "tahu" mengenai kemitraan bank syariah dari reklame/spanduk/iklan sebanyak 67 orang atau 72,43\%, sedangkan masyarakat Kota Bogor yang menjawab sangat tahu tentang bank syariah sebanyak 7 orang atau 9,46\%. Dari perolehan angka penafsiran $\mathrm{M}=3,70$ menunjukkan bahwa masyarakat kota Bogor "tahu" mengenai kemitraan bank syariah dari reklame/spanduk/iklan.

4) Masyarakat mengetahui tentang kemitraan bank syariah dari teman

Dalam Penelitian ini, persepsi masyarakat Kota Bogor terhadap informasi tentang bank syariah ternyata masyarakat Kota Bogor yang "tahu" mengenai informasi tentang kemitraan bank syariah dari teman 
sebanyak 44 orang atau 53,01\%, sedangkan masyarakat kota Bogor yang menjawab sangat tahu mengenai informasi kemitraan bank syariah dari teman sebanyak 5 orang atau 7,53\%. Dari perolehan angka penafsiran $\mathrm{M}=$ 3,32 menunjukkan bahwa pengetahuan masyarakat Kota Bogor tentang informasi bank syariah dari teman adalah" tahu".

5) Masyarakat mengetahui tentang kemitraan bank syariah dari desa/kelurahan

Dalam Penelitian ini, persepsi masyarakat Kota Bogor terhadap informasi tentang bank syariah ternyata masyarakat kota Bogor yang "tahu" mengenai informasi tentang kemitraan bank syariah dari desa/kelurahan sebanyak 17 orang atau 25,10\%, sedangkan masyarakat kota Bogor yang menjawab sangat tahu mengenai informasi kemitraan bank syariah dari desa/kelurahan sebanyak 5 orang atau 1,84\%. Dari perolehan angka penafsiran $\mathrm{M}=2,71$ menunjukkan bahwa pengetahuan masyarakat Kota Bogor tentang informasi bank syariah dari desa/kelurahan adalah " ragu-ragu". Dari data diatas disebabkan ragu-ragu karena desa/kelurahan kurang mensosialisasikan tentang kemitraan bank syariah.

b) Pengetahuan Masyarakat Tentang Kemitraan Bank Syariah
1) Bank Syariah
mengidentifikasi
selalu
masyarakat

Dalam Penelitian ini, pengetahuan masyarakat Kota Bogor mengenai bank syariah selalu mengidentifikasi kebutuhan masyarakat ternyata masyarakat Kota Bogor yang "tahu" mengenai pengetahuan tentang bank syariah selalu mengidentifikasi kebutuhan masyarakat sebanyak 60 orang atau $65,40 \%$, sedangkan masyarakat kota Bogor yang menjawab sangat tahu tentang bank syariah selalu mengidentifikasi kebutuhan masyarakat sebanyak 5 orang atau 6,81\%. Dari perolehan angka penafsiran $\mathrm{M}=3,67$ menunjukkan bahwa masyarakat kota bogor "tahu" mengenai bank syariah selalu mengidentifikasi kebutuhan masyarakat.

2) Bank Syariah selalu berusaha memenuhi kepuasan masyarakat

Dalam Penelitian ini, pengetahuan masyarakat kota Bogor mengenai bank syariah selalu memenuhi kepuasan masyarakat ternyata masyarakat Kota Bogor yang "tahu" mengenai kemitraan bank syariah selalu berusaha memenuhi kepuasan masyarakat sebanyak 56 orang $(60,54 \%)$, sedangkan masyarakat kota Bogor yang menjawab sangat tahu mengenai kemitraan bank syariah selalu berusaha memenuhi kepuasan masyarakat sebanyak 10 orang $(13,51 \%)$. Dari perolehan angka penafsiran $\mathrm{M}=3,70$ menunjukkan bahwa masyarakat kota Bogor mengetahui mengenai kemitraan bank syariah selalu berusaha memenuhi kepuasan masyarakatadalah "tahu".

3) Pola kemitraan pengembangan Bank Syariah yang diikuti dengan lembaga/perusahaan:

Ternyata masyarakat kota Bogor yang "tahu" mengenai pola kemitraan bank syariah yang diikuti dengan lembaga/perusahaan sebanyak 46 orang (54,11\%), sedangkan masyarakat kota Bogor yang menjawab sangat tahu mengenai pola kemitraan bank syariah yang diikuti dengan lembaga/perusahaan sebanyak 4 orang $(5,90 \%)$. Dari perolehan angka penafsiran $\mathrm{M}=3,40$ menunjukkan bahwa masyarakat kota Bogor mengetahui mengenai pola Kemitraan Bank Syariah yang diikuti dengan lembaga/perusahaan adalah "tahu". 
4) Adanya timbal balik keuntungan pada kemitraan bank syariah

Ternyata masyarakat kota Bogor yang "tahu" mengenai adanya timbal balik keuntungan pada kemitraan bank syariah sebanyak 56 orang $(61,70 \%)$, sedangkan masyarakat kota Bogor yang menjawab sangat tahu mengenai adanya timbal balik keuntungan pada kemitraan bank syariah sebanyak 30 orang $(8,26 \%)$. Dari perolehan angka penafsiran $\mathrm{M}=3,63$ menunjukkan bahwa masyarakat kota Bogor mengetahui adanya timbal balik keuntungan pada kemitraan bank syariah adalah "tahu". Dari data diatas dapat disimpulkan bahwa masyarakat mengetahui adanya timbal balik keuntungan pada kemitraan bank syariah karena dengan adanya kemitraan maka pemasaran bank syariah akan lebih banyak diketahui oleh masyarakat.

5) Memberikan pengetahuan tentang produk dan jasa perbankan syariah kepada masyarakat melewati surat kabar atau media elektronik

Berdasarkan penelitian yang dilakukan ternyata masyarakat kota Bogor yang "tahu" mengenai pengetahuan masyarakat kota Bogor mengenai pengetahuan tentang produk dan jasa perbankan syariah kepada masyarakat melewati surat kabar atau media elektronik sebanyak 70 orang (71,06\%), sedangkan masyarakat kota Bogor yang menjawab sangat tahu mengenai pengetahuan masyarakat kota Bogor mengenai pengetahuan tentang produk dan jasa perbankan syariah kepada masyarakat melewati surat kabar atau media elektronik sebanyak 13 orang $(16,50 \%)$. Dari perolehan angka penafsiran $\mathrm{M}=3,94$ menunjukkan bahwa masyarakat kota Bogor mengetahui mengenai pengetahuan tentang produk dan jasa perbankan syariah kepada masyarakat melewati surat kabar atau media elektronik adalah "tahu".

b. Ketertarikan Masyarakat Memanfaatkan Kemitraan Bank Syariah

1) Masyarakat melakukan transaksi pembayaran lain dengan online

Berdasarkan penelitian ternyata masyarakat Kota Bogor yang "tertarik" melakukan transaksi pembayaran lain dengan online sebanyak 53 orang atau $58,24 \%$, sedangkan masyarakat kota Bogor yang menjawab sangat tahu tentang ketertarikan masyarakat melakukan transaksi pembayaran lain dengan online sebanyak 10 orang atau 13,74\%. Dari perolehan angka penafsiran $\mathrm{M}=3,64$ menunjukkan bahwa masyarakat melakukan transaksi pembayaran dengan online adalah " tertarik".

2) Dengan adanya kemitraan bank syariah, masyarakat menjadi lebih ter-edukasi

Dari hasil penelitian ternyata masyarakat Kota Bogor yang "tertarik" dengan adanya kemitraan bank syariah, masyarakat menjadi lebih teredukasi sebanyak 60 orang $(64,17 \%)$, sedangkan masyarakat kota Bogor yang menjawab sangat Setuju tentang adanya kemitraan bank syariah, masyarakat menjadi lebih ter-edukasi sebanyak 21 orang $(25,73 \%)$. Dari perolehan angka penafsiran $\mathrm{M}=3,74$ menunjukkan bahwa masyarakat kota Bogor "tertarik" dalam adanya kemitraan bank syariah, masyarakat menjadi lebih ter-edukasi.

3) Bank syariah mengembangkan pemasaran bisnisnya dengan menjalin kemitraan yang luas

Dari hasil penelitian yang telah dilakukan ternyata masyarakat Kota Bogor yang "tertarik" dalam bank syariah mengembangkan pemasaran bisnisnya dengan menjalin kemitraan yang luas sebanyak 74 orang $(75,51 \%)$, sedangkan masyarakat Kota 
Bogor yang menjawab sangat tertarik tentang sebanyak 10 orang $(12,75 \%)$. Dari perolehan angka penafsiran $\mathrm{M}=$ 3,92 menunjukkan bahwa masyarakat kota Bogor "tertarik" dalam bank syariah mengembangkan pemasaran bisnisnya dengan menjalin kemitraan yang luas.

4) Masyarakat percaya pada profesionalnya kemitraan bank syariah

Berdasarkan hasil penelitian ternyata masyarakat kota Bogor yang "tertarik" dan percaya pada profesionalnya kemitraan bank syariah lain sebanyak 69 orang $(70,40 \%)$, sedangkan masyarakat Kota Bogor yang menjawab sangat tertarik tentang bank syariah sebanyak 12 orang $(15,30 \%)$. Dari perolehan angka penafsiran $\mathrm{M}=3,92$ menunjukkan bahwa masyarakat kota Bogor "tertarik" dalam profesionalnya kemitraan bank syariah.

5) Kemitraan Bank Syariah dapat meningkatkan pertumbuhan ekonomi

Dalam Penelitian ini, ketertarikan masyarakat kota Bogor mengenai Kemitraan Bank Syariah dapat meningkatkan pertumbuhan ekonomi yang "tertarik" sebanyak 67 orang $(65,52)$, sedangkan masyarakat kota Bogor yang menjawab sangat tertarik tentang kemitraan Bank Syariah dapat meningkatkan pertumbuhan ekonomi sebanyak 21 orang atau 25,67\%. Dari perolehan angka penafsiran $\mathrm{M}=4,09$ menunjukkan bahwa masyarakat kota Bogor "tertarik" dalam melakukan kemitraan bank syariah dapat meningkatkan pertumbuhan ekonomi.

c. Persepsi Masyarakat Mengenai Kemitraan Bank Syariah

1) Merupakan kemitraan Bank Syariah yang penuh tanggung jawab

Dalam Penelitian ini, persepsi masyarakat Kota Bogor terhadap kemitraan bank syariah yang penuh tanggung jawab yang "Setuju" sebanyak 66 orang $(64,71 \%)$, sedangkan persepsi masyarakat kota Bogor yang menjawab "sangat Setuju" terhadap kemitraan bank syariah yang penuh tanggung jawab sebanyak 21 orang $(25,73 \%)$. Dari perolehan angka penafsiran $\mathrm{M}=4,08$ menunjukkan bahwa persepsi masyarakat kota Bogor "setuju" mengenai kemitraan bank syariah yang penuh tanggung jawab.

2) Persepsi masyarakat terhadap kemitraan Bank Syariah yang up-todate

Dalam Penelitian ini, persepsi masyarakat kota Bogor terhadap kemitraan Bank Syariah yang up-todate yang "Setuju" sebanyak 62 orang (62,94\%), sedangkan persepsi masyarakat kota Bogor yang menjawab sangat Setuju mengenai kemitraan Bank Syariah yang up-todate sebanyak 16 orang (20,30\%). Dari perolehan angka penafsiran $\mathrm{M}=3,94$ menunjukkan bahwa masyarakat kota Bogor "setuju" mengenai kemitraan Bank Syariah yang up-to-date.

3) Kemitraan Bank Syariah dengan perusahaan/lembaga memiliki kompetensi yang baik

Dalam Penelitian ini, persepsi masyarakat kota Bogor mengenai Kemitraan Bank Syariah dengan perusahaan/lembaga memiliki kompetensi yang baik yang "Setuju" sebanyak 63 orang $(60,14 \%)$, sedangkan persepsi masyarakat kota Bogor yang menjawab "sangat Setuju" mengenai kemitraan Bank Syariah dengan perusahaan/lembaga memiliki kompetensi yang baik sebanyak 28 orang $(33,41 \%)$. Dari perolehan angka penafsiran $\mathrm{M}=3,19$ menunjukkan bahwa masyarakat kota Bogor "setuju" mengenai Kemitraan Bank Syariah dengan perusahaan/lembaga memiliki kompetensi yang baik. 
4) Kemitraan Bank Syariah memiliki kredibilitas

Dalam Penelitian ini, persepsi masyarakat kota Bogor mengenai Kemitraan Bank Syariah memiliki kredibilitas yang "Setuju" sebanyak 70 orang $(66,98 \%)$, sedangkan persepsi masyarakat kota Bogor yang menjawab "sangat Setuju" mengenai Kemitraan Bank Syariah memiliki kredibilitas sebanyak 24 orang $(28,70 \%)$. Dari perolehan angka penafsiran $\mathrm{M}=4,18$ menunjukkan bahwa masyarakat kota Bogor "setuju" mengenai Kemitraan Bank Syariah memiliki kredibilitas.

5) Kemitraan Bank Syariah memiliki manajemen yang baik

Dalam Penelitian ini, persepsi masyarakat kota Bogor mengenai Kemitraan Bank Syariah memiliki manajemen yang baik yang mengungkapkan "Setuju" sebanyak 68 orang $(66,99 \%)$, sedangkan persepsi masyarakat kota Bogor yang menjawab "sangat Setuju" mengenai Kemitraan Bank Syariah memiliki manajemen yang baik sebanyak 19 orang $(23,40 \%)$. Dari perolehan angka penafsiran $\mathrm{M}=4,06$ menunjukkan bahwa masyarakat kota Bogor "setuju" mengenai Kemitraan Bank Syariah memiliki manajemen yang baik.

d. Persepsi masyarakat mengenai reputasi bank syariah

1) Kemitraan Bank Syariah memiliki nama baik

Dalam Penelitian ini, ternyata masyarakat Kota Bogor yang "Setuju" mengenai bank syariah memiliki nama baik sebanyak 63 orang $(59,30 \%)$, sedangkan masyarakat Kota Bogor yang menjawab sangat Setuju tentang bank syariah sebanyak 31 orang (36,47\%). Dari perolehan angka penafsiran $\mathrm{M}=4,25$ menunjukkan bahwa masyarakat kota Bogor "sangat setuju" bank syariah memiliki nama baik.
2) Kemitraan Bank Syariah responsif terhadap masyarakat

Dalam Penelitian ini, ternyata persepsi masyarakat kota Bogor mengenai kemitraan Bank Syariah responsif terhadap masyarakat yang mengungkapkan "Setuju" sebanyak 63 orang (64,61\%), sedangkan masyarakat Kota Bogor yang menjawab sangat Setuju mengenai kemitraan Bank Syariah responsif terhadap masyarakat sebanyak 15 orang $(19,23 \%)$. Dari perolehan angka penafsiran $\mathrm{M}=3,90$ menunjukkan bahwa masyarakat kota Bogor "sangat setuju" mengenai Kemitraan Bank Syariah responsif terhadap masyarakat.

3) Memberi informasi mengenai yang terjadi dalam Bank Syariah

Dalam Penelitian ini, ternyata masyarakat Kota Bogor yang mengungkapkan "Setuju" mengenai memberi informasi mengenai yang terjadi dalam Bank Syariah pada masyarakat sebanyak 49 orang $(53,99 \%)$, sedangkan masyarakat Kota Bogor yang menjawab "sangat setuju" mengenai Setuju informasi yang terjadi dalam Bank Syariah sebanyak 7 orang $(9,64 \%)$. Dari perolehan angka penafsiran $\mathrm{M}=3,63$ menunjukkan bahwa masyarakat kota Bogor "sangat setuju" mengenai informasi yang terjadi pada bank syariah.

4) Menjadi kemitraan Bank Syariah yang mematuhi POJK dan PBI

Dalam Penelitian ini, persepsi masyarakat Kota Bogor terhadap kemitraan Bank Syariah yang mematuhi POJK dan PBI mengungkapkan "Setuju" sebanyak 50 orang (54,50\%), sedangkan masyarakat kota Bogor yang menjawab "sangat Setuju" tentang bank syariah sebanyak 10 orang $(13,62 \%)$. Dari perolehan angka penafsiran $\mathrm{M}=3,67$ menunjukkan 
bahwa masyarakat kota Bogor "setuju" mengenai kemitraan Bank Syariah yang mematuhi POJK dan PBI.

5) Menjadi kemitraan Bank Syariah yang sukses

Dalam Penelitian ini, ternyata masyarakat Kota Bogor yang "Setuju" mengenai kemitraan Bank Syariah yang sukses sebanyak 52 orang atau (49,05\%), sedangkan masyarakat Kota Bogor yang menjawab "sangat Setuju" Menjadi kemitraan Bank Syariah yang sukses sebanyak 36 orang $(42,45 \%)$. Dari perolehan angka penafsiran $\mathrm{M}=4,24$ menunjukkan bahwa masyarakat kota Bogor "sangat setuju" menjadi kemitraan Bank Syariah yang sukses.

5. Analisis Test Chi-Square (Chi Kuadrat)

a. Informasi Kemitraan Bank Syariah

1) Masyarakat mengetahui mengenai kemitraan bank syariah

Berdasarkan hasil perhitungan Chi Kuadrat menunjukkan bahwa nilai Chi Kuadrat hitung $=34,160$, dengan derajat kebebasan $(\mathrm{dk})=\mathrm{n}-1=5-1=4$. Berdasarkan $\mathrm{dk}=4$ dengan taraf signifikan sebesar 1\%, maka diperoleh nilai Chi Kuadrat tabel $=13,277$. Diketahui bahwa nilai Chi Kuadrat hitung lebih besar dari nilai Chi Kuadrat tabel $(34,160>13,277)$. Dengan demikian Ho ditolak dan Ha diterima atau dapat dikatakan bahwa masyarakat Kota Bogor sudah mengetahui informasi kemitraan bank syariah. Hal ini sepadan dengan skala penafsiran, persepsi masyarakat mengenai kemitraan bank syariah. Karena sebagian masyarakat sudah mengetahui program kemitraan bank syariah.

2) Masyarakat mengetahui tentang kemitraan bank syariah dari televisi

Berdasarkan hasil perhitungan Chi Kuadrat menunjukkan bahwa nilai Chi Kuadrat hitung $=36,560^{a}$, dengan derajat kebebasan $(\mathrm{dk})=\mathrm{n}-1=5-1=4$. Berdasarkan $\mathrm{dk}=4$ dengan taraf signifikan sebesar 1\%, maka diperoleh nilai Chi Kuadrat tabel $=13,277$. Diketahui bahwa nilai Chi Kuadrat hitung lebih besar dari nilai Chi Kuadrat tabel $\quad\left(36,560^{a}>13,277\right)$. Dengan demikian Ho ditolak dan Ha diterima atau dapat dikatakan bahwa masyarakat kota Bogor sudah mengetahui informasi kemitraan bank syariah dari televisi. Hal ini sepadan dengan skala penafsiran, persepsi masyarakat mengenai kemitraan bank syariah. Karena sebagian masyarakat sudah mengetahui informasi program kemitraan bank syariah dari televisi.

3) Masyarakat mengetahui kemitraan bank syariah dari reklame/spanduk/iklan

Berdasarkan hasil perhitungan Chi Kuadrat menunjukkan bahwa nilai Chi Kuadrat hitung $=95,360^{\mathrm{a}}$, dengan derajat kebebasan $(\mathrm{dk})=\mathrm{n}-1=5-1=4$. Berdasarkan $\mathrm{dk}=4$ dengan taraf signifikan sebesar 1\%, maka diperoleh nilai Chi Kuadrat tabel $=13,277$. Diketahui bahwa nilai Chi Kuadrat hitung lebih besar dari nilai Chi Kuadrat tabel (95.360 $>$ 13,277). Dengan demikian Ho ditolak dan Ha diterima atau dapat dikatakan bahwa masyarakat kota Bogor sudah mengetahui informasi kemitraan bank syariah dari reklame/spanduk/iklan.

4) Masyarakat mengetahui tentang kemitraan bank syariah dari teman

Berdasarkan hasil perhitungan Chi Kuadrat menunjukkan bahwa nilai Chi Kuadrat hitung $=33.840^{\mathrm{a}}$, dengan derajat kebebasan $(\mathrm{dk})=\mathrm{n}-1=5-1=4$. Berdasarkan $\mathrm{dk}=4$ dengan taraf signifikan sebesar 1\%, maka diperoleh nilai Chi Kuadrat tabel $=13,277$. Diketahui bahwa nilai Chi Kuadrat hitung lebih besar dari nilai Chi Kuadrat tabel (33.840 $>13,277)$. Dengan demikian Ho ditolak dan Ha diterima atau dapat dikatakan bahwa masyarakat kota Bogor sudah mengetahui informasi kemitraan bank syariah dari teman. 
5) Masyarakat mengetahui tentang kemitraan bank syariah dari desa/kelurahan

Berdasarkan hasil perhitungan Chi Kuadrat menunjukkan bahwa nilai Chi Kuadrat hitung $=67.500^{c}$, dengan derajat kebebasan $(\mathrm{dk})=\mathrm{n}-1=5-1=4$. Berdasarkan $\mathrm{dk}=4$ dengan taraf signifikan sebesar $1 \%$, maka diperoleh nilai Chi Kuadrat tabel $=13,277$ (terlampir). Diketahui bahwa nilai Chi Kuadrat hitung lebih besar dari nilai Chi Kuadrat tabel (67.500`> 13,277). Dengan demikian Ho ditolak dan Ha diterima atau dapat dikatakan bahwa masyarakat kota Bogor sudah mengetahui informasi kemitraan bank syariah dari desa/kelurahan. Berdasarkan hasil wawancara dan penyebaran kuesioner diketahui bahwa sebenarnya responden dalam hal ini mengetahui informasi kemitraan bank syariah sehingga mereka memilih "tahu".

b. Pengetahuan Masyarakat tentang Kemitraan Bank Syariah.

1) Kemitraan Bank Syariah selalu mengidentifikasi kebutuhan masyarakat.

Berdasarkan hasil perhitungan Chi Kuadrat menunjukkan bahwa nilai Chi Kuadrat hitung $=86.320$, dengan derajat kebebasan $(\mathrm{dk})=\mathrm{n}-1=5-1=4$. Berdasarkan $\mathrm{dk}=4$ dengan taraf signifikan sebesar 1\%, maka diperoleh nilai Chi Kuadrat tabel $=13,277$ (terlampir). Diketahui bahwa nilai Chi Kuadrat hitung lebih besar dari nilai Chi Kuadrat tabel (86.320 $>13,277)$. Dengan demikian Ho ditolak dan Ha diterima atau dapat dikatakan bahwa masyarakat kota Bogor sudah mengetahui mengenai kemitraan bank syariah selalu mengidentifikasi kebutuhan masyarakat. Hal ini sepadan dengan skala penafsiran, persepsi masyarakat mengenai kemitraan bank syariah.
2) Kemitraan Bank Syariah selalu berusaha memenuhi kepuasan masyarakat

Berdasarkan hasil perhitungan Chi Kuadrat menunjukkan bahwa nilai Chi Kuadrat hitung $=104.700^{c}$, dengan derajat kebebasan $(\mathrm{dk})=\mathrm{n}-1=5-1=4$. Berdasarkan $\mathrm{dk}=4$ dengan taraf signifikan sebesar 1\%, maka diperoleh nilai Chi Kuadrat tabel $=13,277$ (terlampir). Diketahui bahwa nilai Chi Kuadrat hitung lebih besar dari nilai Chi Kuadrat tabel (104.700 $>13,277)$. Dengan demikian Ho ditolak dan Ha diterima atau dapat dikatakan bahwa masyarakat kota Bogor sudah mengetahui mengenai kemitraan bank syariah selalu memenuhi kepuasan masyarakat.

3) Pola kemitraan pengembangan Bank Syariah yang diikuti engan lembaga/perusahaan

Berdasarkan hasil perhitungan Chi Kuadrat menunjukkan bahwa nilai Chi Kuadrat hitung $=80.545^{\mathrm{d}}$, dengan derajat kebebasan $(\mathrm{dk})=\mathrm{n}-1=5-1=4$. Berdasarkan $\mathrm{dk}=4$ dengan taraf signifikan sebesar 1\%, maka diperoleh nilai Chi Kuadrat tabel $=13,277$ (terlampir). Diketahui bahwa nilai Chi Kuadrat hitung lebih besar dari nilai Chi Kuadrat tabel $\left(80.545^{\mathrm{d}>}\right.$ 13,277). Dengan demikian Ho ditolak dan Ha diterima atau dapat dikatakan bahwa masyarakat kota Bogor sudah mengetahui mengenai Pola kemitraan pengembangan Bank Syariah yang diikuti dengan lembaga/perusahaan.

4) Adanya timbal balik keuntungan pada kemitraan bank syariah

Berdasarkan hasil perhitungan Chi Kuadrat menunjukkan bahwa nilai Chi Kuadrat hitung $=116.900^{c}$, dengan derajat kebebasan $(\mathrm{dk})=\mathrm{n}-1=5-1=4$. Berdasarkan $\mathrm{dk}=4$ dengan taraf signifikan sebesar $1 \%$, maka diperoleh nilai Chi Kuadrat tabel $=13,277$ (terlampir). Diketahui bahwa nilai Chi Kuadrat hitung lebih besar dari nilai Chi 
Kuadrat tabel $\left(116.900^{c}>13,277\right)$. Dengan demikian Ho ditolak dan $\mathrm{Ha}$ diterima atau dapat dikatakan bahwa masyarakat kota Bogor sudah mengetahui mengenai Adanya timbal balik keuntungan pada kemitraan bank syariah.

5) Memberikan pengetahuan tentang produk dan jasa perbankan syariah kepada masyarakat melewati surat kabar atau media elektronik.

Berdasarkan hasil perhitungan Chi Kuadrat menunjukkan bahwa nilai Chi Kuadrat hitung $=113.040^{a}$, dengan derajat kebebasan $(\mathrm{dk})=\mathrm{n}-1=5-1=4$. Berdasarkan $\mathrm{dk}=4$ dengan taraf signifikan sebesar 1\%, maka diperoleh nilai Chi Kuadrat tabel $=13,277$ (terlampir). Diketahui bahwa nilai ${ }_{1} \mathrm{Chi}$ Kuadrat hitung lebih besar dari nilai Chi Kuadrat tabel $\left(113.040^{a}>13,277\right)$. Dengan demikian Ho ditolak dan $\mathrm{Ha}$ diterima atau dapat dikatakan bahwa masyarakat kota Bogor sudah mengetahui mengenai pengetahuan tentang produk dan jasa perbankan syariah kepada masyarakat melewati surat kabar atau media elektronik.

Berdasarkan perhitungan Chikuadrat tersebut, sepadan dengan hasil wawancara satu nara sumber kepala Bank Syariah Mandiri cabang Cibubur, bahwa:

a. Konsep kemitraan bussines to bussines ialah kerjasama dengan kementrian agama, dana-dana haji, dan dana yang kaitannya dengan kementrian agama, menjadi bank operasional, untuk pmrintahan seperti dana Bantuan Operasional Siswa (BOS), dana tunjangan PNS dan sebagainya. Dan bank syariah mandiri menjadi salah satu bank operasional pemerintah.

b. Bussines to customer seperti adanya produk musyarakah dan mudharabah. Seperti memenuhi kebutuhan untuk kepemilikan rumah, kepemilikan mobil, pembelian ruko dan sebagainya. Tingkat bisnisnya sangat tinggi secara bussines to customer ada beberapa segmen. Segemen korporasi, komersial, bussines banking ada mikro banking. Sesuai plafond 200 juta ke bawah mikro, lebih dari 200 juta sampai 5 milyar bussines banking. Bussines banking dengan pola kemitraan seperti kemitraan dibidang perkebunan. Contohnya berkerjasama dengan pabrik sawit. Kebanyakan perusahaan kelapa sawit memiliki kebun kelapa sawit sebagai bahan bakunya. Perkebunan kelapa sawit yang digarap oleh para petani dengan luas perkebunan 1-2 hektar. Bank syariah memberikan pembiayaan kepada para petani, pola kemitraan diatas disebut sistem plasma inti, ada perusahaaan induknya ada plasma-plasmanya. Bank syariah memberikan plasmaplasmanya, kalau dengan induknya besar seperti perusahaan sinar mas, WMI dan astra memiliki kebun sawit. Kemitraan dengan mereka dalam rangka pengembangan GKM (Gugus Kendali Mutu) untuk petani. Satu petani memiliki modal antara 100-500 juta.

c. Ketertarikan Masyarakat Memanfaatkan Kemitraan Bank Syariah

1) Masyarakat melakukan transaksi pembayaran lain dengan online

Berdasarkan hasil perhitungan Chi Kuadrat menunjukkan bahwa nilai Chi Kuadrat hitung $=50.960^{\mathrm{a}}$, dengan derajat kebebasan $(\mathrm{dk})=\mathrm{n}-1=5-1=4$. Berdasarkan $\mathrm{dk}=4$ dengan taraf signifikan sebesar 1\%, maka diperoleh nilai Chi Kuadrat tabel $=13,277$ (terlampir). Diketahui bahwa nilai Chi Kuadrat hitung lebih besar dari nilai Chi Kuadrat tabel $\left(50.960^{a}>13,277\right)$. Dengan demikian Ho ditolak dan $\mathrm{Ha}$ diterima atau dapat dikatakan bahwa 
masyarakat kota Bogor tertarik dalam melakukan transaksi pembayaran lain dengan online.

Berdasarkan hal tersebut, sepadan dengan hasil wawancara nara sumber kepala Bank Syariah Mandiri cabang Cibubur, bahwa: Bank Syariah Mandiri menyalurkan Kredit Usaha Rakyat program dari pemerintah. pemerintah.. Selain itu ada dana bergulir, dana-dana bergulir, dana-dana dari Lembaga Amil Zakat. Ada dalam jenis tabrru' dan tijarah.

2) Dengan adanya kemitraan bank syariah, masyarakat menjadi lebih ter-edukasi

Berdasarkan hasil perhitungan Chi Kuadrat menunjukkan bahwa nilai Chi Kuadrat hitung $=82.720^{\mathrm{a}}$, dengan derajat kebebasan $(\mathrm{dk})=\mathrm{n}-1=5-1=4$. Berdasarkan $\mathrm{dk}=4$ dengan taraf signifikan sebesar 1\%, maka diperoleh nilai Chi Kuadrat tabel $=13,277$ (terlampir). Diketahui bahwa nilai Chi Kuadrat hitung lebih besar dari nilai Chi Kuadrat tabel $\left(82.720^{\mathrm{a}}>13,277\right)$. Dengan demikian Ho ditolak dan $\mathrm{Ha}$ diterima atau dapat dikatakan bahwa masyarakat kota Bogor tertarik dalam adanya kemitraan bank syariah, masyarakat menjadi ter-edukasi.

3) Bank syariah mengembangkan pemasaran bisnisnya dengan menjalin kemitraan yang luas

Berdasarkan hasil perhitungan Chi Kuadrat menunjukkan bahwa nilai Chi Kuadrat hitung $=131.040^{a}$, dengan derajat kebebasan $(\mathrm{dk})=\mathrm{n}-1=5-1=4$. Berdasarkan $\mathrm{dk}=4$ dengan taraf signifikan sebesar 1\%, maka diperoleh nilai Chi Kuadrat tabel $=13,277$ (terlampir). Diketahui bahwa nilai Chi Kuadrat hitung lebih besar dari nilai Chi Kuadrat tabel $\left(131.040^{\mathrm{a}}>13,277\right)$. Dengan demikian Ho ditolak dan $\mathrm{Ha}$ diterima atau dapat dikatakan bahwa masyarakat kota Bogor tertarik bahwa Bank syariah mengembangkan pemasaran bisnisnya dengan menjalin kemitraan yang luas.Masyarakat percaya pada profesionalnya kemitraan bank syariah

Berdasarkan hasil perhitungan Chi Kuadrat menunjukkan bahwa nilai Chi Kuadrat hitung $=109.200^{a}$, dengan derajat kebebasan $(\mathrm{dk})=\mathrm{n}-1=5-1=4$. Berdasarkan $\mathrm{dk}=4$ dengan taraf signifikan sebesar 1\%, maka diperoleh nilai Chi Kuadrat tabel $=13,277$ (terlampir). Diketahui bahwa nilai Chi Kuadrat hitung lebih besar dari nilai Chi Kuadrat tabel (109.200 a 13,277). Dengan demikian Ho ditolak dan $\mathrm{Ha}$ diterima atau dapat dikatakan bahwa masyarakat kota Bogor tertarik bahwa masyarakat percaya pada profesionalnya kemitraan bank syariah.

4) Kemitraan Bank Syariah dapat meningkatkan pertumbuhan ekonomi

Berdasarkan hasil perhitungan Chi Kuadrat menunjukkan bahwa nilai Chi Kuadrat hitung $=52.220^{\mathrm{e}}$, dengan derajat kebebasan $(\mathrm{dk})=\mathrm{n}-1=5-1=4$. Berdasarkan $\mathrm{dk}=4$ dengan taraf signifikan sebesar 1\%, maka diperoleh nilai Chi Kuadrat tabel $=13,277$ (terlampir). Diketahui bahwa nilai Chi Kuadrat hitung lebih besar dari nilai Chi Kuadrat tabel $\left(52.220^{\mathrm{e}}>13,277\right)$. Dengan demikian Ho ditolak dan $\mathrm{Ha}$ diterima atau dapat dikatakan bahwa masyarakat kota Bogor tertarik bahwa Kemitraan Bank Syariah dapat meningkatkan pertumbuhan ekonomi.

c. Persepsi masyarakat mengenai kemitraan bank syariah

1) Merupakan kemitraan Bank Syariah yang penuh tanggung jawab

Berdasarkan hasil perhitungan Chi Kuadrat menunjukkan bahwa nilai Chi Kuadrat hitung $=48.980 \mathrm{e}$, dengan derajat kebebasan $(\mathrm{dk})=\mathrm{n}-1=5-1=4$. Berdasarkan $\mathrm{dk}=4$ dengan taraf signifikan sebesar 1\%, maka diperoleh nilai Chi Kuadrat tabel $=13,277$ (terlampir). Diketahui bahwa nilai Chi Kuadrat hitung lebih besar dari nilai Chi 
Kuadrat tabel (48.980e $>13,277)$. Dengan demikian Ho ditolak dan $\mathrm{Ha}$ diterima atau dapat dikatakan bahwa masyarakat kota Bogor tertarik dengan kemitraan Bank Syariah yang penuh tanggung jawab.

2) Merupakan kemitraan Bank Syariah yang up-to-date

Berdasarkan hasil perhitungan Chi Kuadrat menunjukkan bahwa nilai Chi Kuadrat hitung $=37,520$, dengan derajat kebebasan $(\mathrm{dk})=\mathrm{n}-1=5-1=4$. Berdasarkan $\mathrm{dk}=4$ dengan taraf signifikan sebesar 1\%, maka diperoleh nilai Chi Kuadrat tabel $=13,277$ (terlampir). Diketahui bahwa nilai Chi Kuadrat hitung lebih besar dari nilai Chi Kuadrat tabel $\left(37,520^{e}>13,277\right)$. Dengan demikian Ho ditolak dan $\mathrm{Ha}$ diterima atau dapat dikatakan bahwa masyarakat kota Bogor tertarik dengan kemitraan Bank Syariah yang up-to-date.

3) Kemitraan Bank Syariah dengan perusahaan/lembaga memiliki kompetensi yang baik

Berdasarkan hasil perhitungan Chi Kuadrat menunjukkan bahwa nilai Chi Kuadrat hitung $=45,020^{\mathrm{e}}$, dengan derajat kebebasan $(\mathrm{dk})=\mathrm{n}-1=5-1=4$. Berdasarkan $\mathrm{dk}=4$ dengan taraf signifikan sebesar 1\%, maka diperoleh nilai Chi Kuadrat tabel $=13,277$ (terlampir). Diketahui bahwa nilai Chi Kuadrat hitung lebih besar dari nilai Chi Kuadrat tabel $\left(45,020^{\mathrm{e}}>13,277\right)$. Dengan demikian Ho ditolak dan $\mathrm{Ha}$ diterima atau dapat dikatakan bahwa masyarakat kota Bogor tertarik dengan kemitraan Bank Syariah memiliki kompetensi yang baik.

4) Kemitraan Bank Syariah memiliki kredibilitas

Berdasarkan hasil perhitungan Chi Kuadrat menunjukkan bahwa nilai Chi Kuadrat hitung $=65.360^{\mathrm{e}}$, dengan derajat kebebasan $(\mathrm{dk})=\mathrm{n}-1=5-1=4$. Berdasarkan $\mathrm{dk}=4$ dengan taraf signifikan sebesar 1\%, maka diperoleh nilai Chi Kuadrat tabel $=13,277$ (terlampir). Diketahui bahwa nilai Chi Kuadrat hitung lebih besar dari nilai Chi Kuadrat tabel $\left(65.360^{\mathrm{e}}>13,277\right)$. Dengan demikian Ho ditolak dan $\mathrm{Ha}$ diterima atau dapat dikatakan bahwa masyarakat kota Bogor setuju dengan kemitraan Bank Syariah memiliki kredibilitas.

5) Kemitraan Bank Syariah memiliki manajemen yang baik

Berdasarkan hasil perhitungan Chi Kuadrat menunjukkan bahwa nilai Chi Kuadrat hitung $=54.620^{2}$., dengan derajat kebebasan $(\mathrm{dk})=\mathrm{n}-1=5-1=4$. Berdasarkan $\mathrm{dk}=4$ dengan taraf signifikan sebesar 1\%, maka diperoleh nilai Chi Kuadrat tabel $=13,277$ (terlampir). Diketahui bahwa nilai Chi Kuadrat hitung lebih besar dari nilai Chi Kuadrat tabel $\left(45,020^{\mathrm{e}}>\quad 13,277\right)$. Dengan demikian Ho ditolak dan $\mathrm{Ha}$ diterima atau dapat dikatakan bahwa masyarakat kota Bogor "setuju" dengan kemitraan Bank Syariah memiliki manajemen yang baik.

Dalam hal perhitungan chi-kuadrat tersebut dapat disimpulkan bahwa sepadan dengan hasil wawancara dengan narasumber kepala BSM cabang Cibubur, yaitu: Dalam misinya yang ke 4 mengembangkan usaha mikro kecil dan menengah. Jadi tidak mungkin mengkesamipingkan hal itu. BSM memperhatikan ritel dan juga tidak mengkesampingkan korporasi dan sindikasi.

d. Persepsi Masyarakat mengenai Reputasi Bank Syariah

1) Kemitraan Bank Syariah memiliki nama baik

Berdasarkan hasil perhitungan Chi Kuadrat menunjukkan bahwa nilai Chi Kuadrat hitung $=48.980^{\mathrm{e}}$., dengan derajat kebebasan $(\mathrm{dk})=\mathrm{n}-1=5-1=4$. Berdasarkan $\mathrm{dk}=4$ dengan taraf signifikan sebesar 1\%, maka diperoleh nilai Chi Kuadrat tabel $=13,277$ (terlampir). Diketahui bahwa nilai Chi Kuadrat hitung lebih besar dari nilai Chi 
Kuadrat tabel (48.980e $>13,277)$. Dengan demikian Ho ditolak dan $\mathrm{Ha}$ diterima atau dapat dikatakan bahwa masyarakat kota Bogor "setuju" dengan kemitraan Bank Syariah memiliki manajemen yang baik.

2) Kemitraan Bank Syariah responsif terhadap masyarakat

Berdasarkan hasil perhitungan Chi Kuadrat menunjukkan bahwa nilai Chi Kuadrat hitung $=12,160^{a}$., dengan derajat kebebasan $(\mathrm{dk})=\mathrm{n}-1=5-1=4$. Berdasarkan $\mathrm{dk}=4$ dengan taraf signifikan sebesar 1\%, maka diperoleh nilai Chi Kuadrat tabel $=13,277$ (terlampir). Diketahui bahwa nilai Chi Kuadrat hitung lebih besar dari nilai Chi Kuadrat tabel $\left(48.980^{\mathrm{e}}>13,277\right)$. Dengan demikian Ho ditolak dan $\mathrm{Ha}$ diterima atau dapat dikatakan bahwa masyarakat kota Bogor "setuju" bahwa kemitraan Bank Syariah responsif terhadap masyarakat.

3) Memberi informasi mengenai yang terjadi dalam Kemitraan Bank Syariah

Berdasarkan hasil perhitungan Chi Kuadrat menunjukkan bahwa nilai Chi Kuadrat hitung $=31,580^{\mathrm{e}}$., dengan derajat kebebasan $(\mathrm{dk})=\mathrm{n}-1=5-1=4$. Berdasarkan $\mathrm{dk}=4$ dengan taraf signifikan sebesar 1\%, maka diperoleh nilai Chi Kuadrat tabel $=13,277$ (terlampir). Diketahui bahwa nilai Chi Kuadrat hitung lebih besar dari nilai Chi Kuadrat tabel $\left(31,580^{\mathrm{e}}>13,277\right)$. Dengan demikian Ho ditolak dan $\mathrm{Ha}$ diterima atau dapat dikatakan bahwa masyarakat kota Bogor "setuju" bahwa Memberikan informasi mengenai yang terjadi dalam Kemitraan Bank Syariah.

Dapat disimpulkan dalam hasil perhitungan Chi-Kuadrat pada Informasi pengetahuan mengenai kemitraan bank syariah. Bahwa hal tersebut, sepadan dengan hasil wawancara dengan responden dan salah satu nara sumber kepala Bank Syariah Mandiri cabang Cibubur, bahwa: a) Responden mengetahui kemitraan bank syariah dari keluarganya yang berkerja di salah satu bank syariah.

b) Responden mengetahui kemitraan bank syariah dengan salah satu lembaga koperasi, sehingga masyarakat lebih mudah meminjam dengan prosedur yang relatif mudah di lembaga simpan pinjam. Dimana lembaga koperasi itu berkerjasama dengan Bank Syariah.

c) Menurut narasumber bapak Haryadi mengenai informasi kemitraan bank syariah di publish di semua media masa, eleaktronik dan sebagainya, guna untuk memperiklankan bank syariah kepada masyarakat dan memperluas pemasaran bisnis.

4) Menjadi kemitraan Bank Syariah yang mematuhi POJK dan PBI

Berdasarkan hasil perhitungan Chi Kuadrat menunjukkan bahwa nilai Chi Kuadrat hitung $=59,120^{\mathrm{a}}$, dengan derajat kebebasan $(\mathrm{dk})=\mathrm{n}-1=5-1=4$. Berdasarkan $\mathrm{dk}=4$ dengan taraf signifikan sebesar 1\%, maka diperoleh nilai Chi Kuadrat tabel $=13,277$ (terlampir). Diketahui bahwa nilai Chi Kuadrat hitung lebih besar dari nilai Chi Kuadrat tabel $\left(59,120^{\mathrm{a}}>13,277\right)$. Dengan demikian Ho ditolak dan $\mathrm{Ha}$ diterima atau dapat dikatakan bahwa masyarakat kota Bogor "setuju" bahwa kemitraan Bank Syariah yang mematuhi POJK dan PBI.

5) Menjadi kemitraan Bank Syariah yang sukses

Berdasarkan hasil perhitungan Chi Kuadrat menunjukkan bahwa nilai Chi Kuadrat hitung $=24,320^{\mathrm{e}}$, dengan derajat kebebasan $(\mathrm{dk})=\mathrm{n}-1=5-1=4$. Berdasarkan $\mathrm{dk}=4$ dengan taraf signifikan sebesar 1\%, maka diperoleh nilai Chi Kuadrat tabel $=13,277$ (terlampir). Diketahui bahwa nilai Chi Kuadrat hitung lebih besar dari nilai Chi Kuadrat tabel $\left(59,120^{a}>13,277\right)$. Dengan demikian Ho ditolak dan $\mathrm{Ha}$ 
diterima atau dapat dikatakan bahwa masyarakat kota Bogor "setuju" bahwa kemitraan Bank Syariah yang mematuhi POJK dan PBI.

Dalam hal perhitungan chi-kuadrat tersebut dapat disimpulkan bahwa sepadan dengan hasil wawancara dengan narasumber kepala BSM cabang Cibubur, yaitu:

a. Informasi bank syariah terbuka , bank syariah sudah diatur oleh Otoritas Jasa Keuangan (OJK) dan bank Indonesia. Terbuka untuk jumlah asset, dan jumlah pembiayan. Di publish di media masa setiap 3 bulan sekali. Bank syariah selalu menyampaikan kepada deposan untuk menjelaskan tentang nisbahnya dalam setiap bulan.

b. Kemitraan dan reputasi saling berkaitan, karena apabila kemitraan yang dijalinnya baik, maka akan menghasilkan keuntungan dan reputasi.

\section{KESIMPULAN DAN IMPLIKASI}

Berdasarkan hasil penelitian, maka dapat disimpulkan oleh penulis dapat mengambil kesimpulan sebagai berikut :

1. Berdasarkan hasil perhitungan Chi Kuadrat pada semua faktor yang dinilai tentang persepsi masyarakat kota Bogor menunjukkan bahwa nilai Chi Kuadrat hitung lebih besar dibandingkan nilai Chi Kuadrat tabel yang berarti Ho ditolak dan $\mathrm{Ha}$ diterima, artinya masyarakat kota Bogor sudah mengetahui kemitraan bank syariah dan reputasi bank syariah.

2. Berdasarkan hasil wawancara yang dilakukan kepada kepala BSM cabang Cibubur dan sejumlah responden diketahui bahwa berpengaruh adanya kemitraan terhadap reputasi bank syariah tersebut karena dapat menimbulkan keuntungan dan reputasi yang baik.

3. Kemitraan bank syariah berpengaruh besar terhadap pertumbuhan ekonomi, pemasaran bisnis, dan pengetahuan masyarakat.

\section{Saran}

Berdasarkan kesimpulan yang telah disebutkan di atas, penulis memberikan saran sebagai berikut:

a. Dengan adanya kemitraan ini, sebaiknya masyarakat dapat lebih mengetahui untuk mengambil manfaat dengan adanya program kerjasama ini.

b. Bank syariah perlu mengadakan sosialisasi mengenai kemitraan bank syariah, sehingga masyarakat lebih mengetahui dan menyadari tentang adanya kemitraan ini agar masyarakat lebih merasakan dampak positif dari adanya program kemitraan pada bank syariah.

\section{DAFTAR PUSTAKA}

\section{Undang-Undang dan Peraturan}

Undang-Undang Nomor 21 Tahun 2008 tentang Perbankan Syariah

\section{Buku}

Ahmad, Abdul Aziz An-najjer dkk, Alih bahasa Salman Haris.1993. 100 soal Jawab TentangBank Islam, Penerbit PT. Al-Maarif: Bandung.

Bateman, snell.2008. Manajemen Kepemimpinan dan Kolaborasi Dalam Dunia Yang Kompetitif.Penerbit : Salemba Empat. Jakarta.

Jafar Hafsah, Muhammad.1999. Kemitraan Usaha, Pustaka Sinar Harapan: Jakarta

Mardikanto, Totok. 2014. CSR Corporate Social Responsibility (Tanggung jawab Sosial Korporasi). Penerbit : ALFABETA. Bandung. 
Remy Sjahdeini, Sutan. 2014. Perbankan Syariah Produk-produk dan Aspekaspek Hukumnya.Penerbit : Kencana Prenadamedia Group. Jakarta.

Sugiyono. 2015. Metode Penelitian Kombinasi(Mixed Methods). Penerbit ALFABETA: Bandung.

Waskito, A.A. Kamus Praktis Bahasa Indonesia. Penerbit : Media

\section{Skripsi dan Tesis}

Alfu Laila, Nur (062411087), dengan judul "Pengaruh Marketing Syariah terhadap Reputasi dan Kepuasan Nasabah PT. Bank Tabungan Negara (Persero) Tbk Kantor Cabang Syariah", skripsi(Semarang : IAIN Walisongo).

Alhifni, Anas. 2012. "Persepsi Santri terhadap perbankan syariah", Skripsi, (Bogor: Universitas Djuanda).

Fadhilah, Sri."Efektivitas Pola Kemitraan dalam Kerjasama Bank Muamalat Indonesia Dengan Mega Life Cabang Syariah Dalam Mengembangkan Sharia Mega Cover", skripsi (Jakarta: UIN SyarifHidayatullah)

Yuana Tobing. 2000. "Hubungan antara Performance Quality dengan Customer Oriented", Tesis, (Semarang: Universitas Diponegoro).

\section{Jurnal}

Noviawaty."Hubungan Antara Faktor Penduduk Setempat Terhadap Kecendrungan Preferensinya", Jurnal (Sumatra : Universitas Sriwijaya)

\section{Internet}

http://Ekbis.sindonews.com diunduh pada hari selasa 01/04/2016 pada pukul $11.00 \mathrm{WIB}$

http://M.rakyatbekasi.com diunduh pada hari selasa 01/04/2016 pada pukul 16.02 WIB http://www.syariahmandiri.co.id/2010 /07/umkm-jadi-andalanpendongkrak-pembiayaansyariah/ diunduh pada hari selasa 01/04/2016 pada pukul 17.00 